\title{
Going green: an SMME perspective
}

\author{
Suzette Viviers
}

Department of Business Management

Nelson Mandela Metropolitan University

suzette.viviers@nmmu.ac.za

\begin{abstract}
The purpose of this research was to investigate the level of environmental awareness and engagement among local SMME owners/managers. The views of 250 SMME owners/managers in the Nelson Mandela Bay region were obtained by means of a survey questionnaire. The findings indicate that respondents are becoming more aware of the impact of their actions on the natural environment and engage in actions to reduce electricity use, recycle paper and replace hazardous materials. Most respondents, however, view environmental management as costly and consider stricter environmental legislation and enforcement, as well as tax incentives, as effective measures to promote "greener" business practices among South African businesses.
\end{abstract}

Key words and phrases: Environmental management; environmental legislation; "going green”; SMMEs; environmental tax incentives

\section{Introduction}

The need to conserve our natural environment and reduce the factors causing climate change has been widely advocated in recent years (Stern, 2007; Mitchell \& Quinn, 2005:19; De Villiers, 2004:21). In recognition of the financial implications of climate change, a growing number of businesses are "going green" (Dahlmann, Brammer \& Millington, 2008:264). Environmental management efforts are, however, mainly limited to large businesses, as Small, Medium and Micro Enterprises (SMMEs) are often constrained by a lack of resources and skills (Mahadea \& Pillay, 2008:431; Maas \& Herrington, 2006; Clover \& Darroch, 2005:238).

\section{Problem statement}

Given the lack of in-depth research on environmental management in the South African SMME sector, the problem statement of this study was to investigate the level of environmental awareness and engagement among SMME owners/managers. Their views on the financial implications of "going green" and the most effective measures to promote the environmental agenda in South Africa were also obtained. Attention was further given to "green" actions currently undertaken by respondents. To give effect to the primary objective of this research, a number of secondary objectives were formulated, namely:

to conduct a literature review on:

o the definition of "going green";

0 the level of environmental awareness and engagement among SMME owners/managers;

0 the financial implications of "going green";

o “green” business practices; and 
o measures to promote "greener" business practices in South Africa.

to empirically investigate the views of a sample of SMME owners/managers in the

Nelson Mandela Bay region by means of a survey questionnaire.

A review of the relevant literature is presented next, followed by a discussion of the research design and methodology, empirical results, pertinent conclusions and recommendations.

\section{Literature review}

\section{The definition of "going green"}

Although different definitions of "going green" exist, the term generally refers to the actions of individuals, businesses and governments to protect the quality and continuity of life through the conservation of natural resources and the prevention of pollution (Lesourd \& Schilizzi, 2001:36; Newton, 2005:3). According to Peattie (1995:25), a "green" business is one that deliberately chooses to incorporate environmental and sustainable development considerations into its business plan and operations. Sustainable development, as defined by the World Commission on Environment and Development (1987:1), refers to "...development that meets the needs of the present without compromising the ability of future generations to meet their own need”.

\section{The level of environmental awareness and engagement among SMME owners/managers}

Although only a few studies exist on environmental management in the SMME sector, most indicate that SMME owners/managers are reluctant to "go green". Horobin and Long (1996:17) conducted a study among small tourism operators in the United Kingdom (UK) and found that the majority of respondents were prepared to accept the link between the natural environment and their businesses, but had either not consciously made the connection before or lacked the motivation or time to act on their beliefs. Many were also unaware of the different types of "green" actions they could undertake to promote sustainable development in their sector.

Only a small number of SMME owners/managers in Horobin and Long's (1996:18) study engaged in "green" actions and most followed a very ad hoc approach to doing so. Few saw the need to adopt an integrated environmental policy. Of those respondents who did not undertake any "greening" actions, most had not felt it necessary to act, others did not see what they personally could do and some simply did not get to do anything about it. Another study in the UK also revealed that small business owners were not convinced of the need to "go green". Many respondents in this study argued that there was not enough time in their day to pursue greening measures that were not a natural by-product of their core activities (SMEs ‘not convinced of need to go green', 2004:6).

A more recent study in the UK, conducted by Dahlmann et al. (2008:264), showed that more UK firms, including SMMEs, were starting to implement measures to reduce their ecological footprint. Although the majority of respondents in their sample initiated steps to become "greener", the findings reveal that they were primarily motivated by economic considerations (such as cost and risk management) and achieving compliance with environmental legislation. The researchers showed that SMMEs in particular rely on 
short planning horizons, which prevent them from becoming more proactive in their environmental outlook. Similar findings were observed by Yu and Bell (2007:19), who found that a high level of concern for the environment by Chinese SMME owners/managers was not mirrored by a high level of engagement. The main motivators for "going green" in this Chinese sample were an improved corporate image and legislative compliance.

In South Africa a number of large businesses have actively embraced the notion of “going green”, Woolworths being a prime example (Salgado, 2008:25; Mokgata, 2008). The growing level of importance attached to improved environmental management practices by large South African businesses could be attributed to developments such as:

the promulgation of new environmental regulations in recent years (Church, 2006:628);

the stricter enforcement of green laws (Ensor, 2008; Benjamin, 2007);

the introduction of "green" tax incentives (Schubert \& Nel, 2008);

the introduction of carbon taxes (SA considering carbon taxes, 2008);

the establishment of a Green Building Council in South Africa (Robertson, 2008:6);

increased demand from consumers for environmentally friendly products and services. (Le Riche (2008:26) argues that South African consumers, like their international counterparts, are becoming increasingly responsible and informed when it comes to environmental matters. "Today's consumers want to know about where, how, when and what in even the most mundane products and are concerned about the impact their purchases will have on the environment and their health.”);

more institutional investors integrating environmental considerations into their investment analyses and ownership practices (Viviers, Bosch, Smit \& Buijs, 2008:15; Cameron, 2006).

The question remains, however, to what extent SMME owners/managers in South Africa are aware of these developments and how willing and able they are to adopt "greener" business practices. Although no statistics are available on the effect that local SMMEs have on the natural environment, it is estimated to be quite significant when considering the size of the sector as a whole (Kapelus, Hamman, Agbazue \& Hein, 2004:54). According to the South African Business Guidebook 2005/2006 (2006:26), SMMEs account for approximately 60 percent of employment in the formal sector and contribute almost 30 percent to the Gross Domestic Product.

In the UK it is estimated that SMMEs are responsible for 60 percent of the industry's carbon dioxide emissions, 60 percent of commercial waste and eight out of ten pollution accidents (SMEs 'not convinced of need to go green', 2004:6). One of the reasons for the general absence of environmental management among SMMEs relates to the perception of costs being too high.

\section{Financial implications of "going green”}

Several authors point out that the initial costs associated with "going green" can be quite high, but also show that businesses can expect savings in the long run that will offset the initial costs (Lesourd \& Schilizzi, 2001:150; Newton, 2005:144). According to Peattie (1995:40), the following costs are to be expected when a firm decides to "go green":

Primary product costs may increase.

Capital expenditure, such as facility changes, may increase. 
Costs may be incurred by complying with new "green” legislation.

"Green" overheads may be incurred by changing the management of the firm.

Costs associated with carbon taxes and fines may be incurred.

In addition to the costs suggested above, firms should also communicate their "green" efforts to the public to gain respect and recognition as a "green" business. It is crucial that consumers be well informed about the "green" features of new and existing products and services, as uncertainty and misleading labelling could lead to lower sales (Hopfenbeck, 1992:113).

SMME owners/managers who decide to "go green" need to ensure that the costs incurred do not exceed the derived benefits thereof. The main benefits associated with improved environmental management include better customer relations, enhanced public and brand image and operational savings. According to Peattie (1995:42) and Lesourd and Schilizzi (2001:38), benefits which could offset additional "greening" costs include indirect savings resulting from the reduction of raw materials, energy, water, office suppliers, heating, lighting and unnecessary packaging, and direct savings in the form of lower waste disposal costs as well as additional income from the sale of by-products.

Millet (2000:5) claims that "green” businesses, irrespective of size, enjoy a competitive advantage in that their customers are less likely to migrate to competing firms. Moreover, environmentally conscious customers are often willing to pay premium prices for environmentally friendly goods and services (Cairncross, 1995:67; Grove, Fisk, Pickett \& Kangun, 1996:56). It has been estimated that small manufacturing concerns in the United States of America (USA) have benefited from mark-ups of between 20 and 30 percent on "green" products and services (Do you need to be green?, 2006). In another North American study it was reported that 45 percent of SMME owners/managers believed that their customers would be willing to pay more for eco-friendly products and services (Go green ..., 2006).

"Going green" can also have a positive effect on staff morale. Employees are often the initiators of improved environmental practices, and firms that adhere to employees' requests for "greener" business practices will boost staff morale and productivity. Millet (2000:5) claims that "people may feel a renewed sense of meaning in their work and have the sense that they are contributing to important work if businesses take on an environmental approach".

In an extensive SMME study by Clemens (2006:492), a strong positive relationship was found between "green" and financial performance, which supports similar findings among larger businesses (Sharma \& Vrendenburg, 1998:729; Hills, Lam \& Welford, 2004:223). It is however important to note that not all "green" actions increase the value of the firm. According to Schaltegger and Figge (1998:11), value is only created when environmental measures are:

capital extensive; for instance when end-of-pipe installations (such as downstream air filters and effluent treatment plants) are "smart", small and cheap;

low material-consuming; for example when the consumption of raw materials is reduced and waste minimised;

sales boosting; for instance when products with "green" benefits for consumers are designed; 
margin widening; as when "green" products boost sales and eco-friendly production techniques reduce operating costs and carbon taxes;

lowering the firm's weighted average costs of capital (WACC); for example. when debt capital is sourced at favourable interest rates (in which case reference is made to a "green loan"); and

long-term value-enhancing; for instance when premium prices charged for "green" products and services can be sustained.

\section{“Green” business practices}

The development of a formal environmental management system will assist SMME owners/managers who wish to "go green" to do so in a systematic and cost-effective manner. Millet (2000:233) sets out a number of steps for the development of an environmental management system. These include the following:

Initial commitment: this stage comprises the realisation by top management (or the owner in the case of the SMME) that there is a need for change. Lesourd and Schilizzi (2001:58) and Clark (2007) point out that strong leadership and commitment from top management are critical for the success of any environmental management system.

Review: subsequently a thorough investigation needs to be undertaken of the environmental risks facing the firm, as well as the potential costs and benefits of "going green”. During this stage top management should calculate their firm's environmental footprint and assess "green" opportunities which present themselves in local and global markets (Burger, 2007).

Developing and publishing an environmental policy: in this step some critical "green" issues need to be identified and addressed by formulating a comprehensive environmental policy. This process may include setting targets for waste reduction and recycling, designing new "green" products, using alternative energy sources and informing consumers about the "greening" of the firm (Hopfenbeck, 1992:120). These targets should be set in line with regulatory requirements.

Preparing and implementing action plans: management then needs to formulate and implement specific action plans to meet the stated policy goals. It is important at this stage that employees are adequately trained and that management set the example (McDonagh \& Prothero, 1997:321).

Monitoring, auditing and reporting progress: once an appropriate environmental management system is in place, progress against the stated goals should be regularly assessed and corrective action taken where necessary (McDonagh \& Prothero, 1997:321).

A myriad of "greening" actions can be undertaken by SMMEs. These could deal with the prevention of air, water and soil pollution by reducing the use of hazardous materials and waste by replacing them with safer alternatives. Examples of hazardous materials include cleaning products, disinfectants, sanitisers and pesticides, fluorescent light bulbs/tubes, batteries, oil, grease, paint and toner cartridges. Other "greening" actions could focus on the reduction of solid waste, which refers to discarded materials other than fluids such as glass, paper, paperboard, food residues, textiles, plastics and sludge formed in sewage treatment systems. Solid waste programmes often focus on the "triple R's”: reducing, reusing and recycling. 
Recent studies among SMMEs in China and Japan show that their "greening" actions centre mainly on improving energy efficiency and implementing cleaner production technologies (Yu \& Bell, 2007:29; Revell, 2002:291). Given the current energy crisis in South Africa, local SMMEs could also focus their "greening" actions on conserving electricity. Lower electricity production (which is based on the burning of coal) will also improve South Africa's per capita carbon dioxide $\left(\mathrm{CO}_{2}\right)$ emissions ratio, which is currently equal to 7.4 metric tonnes per annum, compared with the global average of approximately 4 metric tonnes per annum (South Africa. DEAT, 2006:223). A looming water shortage should also prompt local SMME owners/managers to re-evaluate their use of this finite natural resource.

\section{Measures to promote “greener" business practices}

Shange (2008:90) investigated eight measures which could promote "greener" business practices among South African firms. These measures were:

growing numbers of responsible investors internationally and in South Africa; growing numbers of "green" funds;

the establishment of stock market indices using ethical as well as environmental, social and corporate governance selection criteria;

the development of a carbon credits market;

increasing pressure from banks;

increasing pressure from consumers and consumer groups;

new and better enforced environmental legislation; and progressive environmental tax incentives.

Eighty five percent of respondents in Shange's (2008:99) study (most of whom were asset managers) stated that environmental legislation would be the most effective measure to promote "greener" business practices in South Africa. The respondents were, however, of the opinion that the effectiveness of such legislation was entirely dependent on the adequate enforcement thereof. Stricter environmental legislation has also been proposed by Dahlmann et al. (2008:266) and Yu and Bell (2007:35) as an effective measure to promote "greener" business practices in the UK and China respectively.

Respondents in Shange's (2008:105) study were also in favour of "green” tax incentives to grow the environmental agenda in South Africa. In his 2008/2009 budget speech, the South African Minister of Finance, Trevor Manuel, announced measures to this effect. He stated that the National Treasury was looking at a range of environmental fiscal measures including emission charges and tradable permits as well as tax incentives for cleaner production technologies (Schubert \& Nel, 2008). One particular incentive refers to the introduction of Section 37B, a new provision of the Income Tax Act (Act 58 of 1962 as amended). This section of the Act will provide tax relief for capital expenditure by local manufacturers (including SMMEs) on measures that will protect the environment.

\section{Summary}

In this section it was shown that SMMEs are increasingly becoming concerned about the impact that their businesses are having on the natural environment, yet they do little about it. It was also shown that "going green" has definite financial benefits for SMMEs in terms of an improved corporate image and cost savings. It was suggested that SMME 
owners/managers should develop environmental management systems to structure their "greening" efforts. "Greening" actions often centre on preventing pollution, reducing solid waste and conserving energy and water. International studies suggest that environmental legislation is the most effective measure to promote the "green" agenda in the private sector. In the next section more details are given on the research design and methodology of this study.

\section{Research methodology}

The adoption of a positivistic research paradigm for this study called for the collection and analysis of quantitative data. A survey questionnaire was thus developed to give effect to the problem statement and research objectives of this study. Open-ended and closed questions were formulated, based on the literature review. In Section A, the level of environmental awareness and engagement among local SMME owners/managers was evaluated, as well as SMME owners'/managers' views on the financial implications of "going green" and measures to promote "greener" business practices in the country. Respondents' perceptions were obtained using a five-point Lickert scale where (1) indicated Strongly disagree; (2) = Disagree; (3) = Neutral; (4) = Agree and (5) = Strongly agree.

Section B of the questionnaire dealt with a variety of "green" business actions which could be undertaken. Respondents were asked to indicate whether they were currently undertaking a specific "green" action (Yes/No). If they were not, a further question was posed to ascertain whether they would consider undertaking the action within the next 12 months. Four broad categories of "green" actions were evaluated, namely pollution prevention, solid waste reduction, energy conservation and water conservation. It should be noted that the "green" actions contained in Section B do not represent an exhaustive list, but rather provide examples of generic "greening” actions.

Finally, Section C requested biographical information of the respondents (gender, level of education and total number of years of business experience) and their businesses (branch of industry and number of full-time employees).

The target population of the study comprised all SMMEs operating in the Nelson Mandela Bay region, irrespective of industry. Although no statistics are available on the exact number of SMMEs operating in the Nelson Mandela Bay region, it is estimated that there might be as many as 18000 (Mattheus, personal communication, 2007). To address the problem of low response rates associated with mail and telephonic interviews, questionnaires were personally delivered to the owners or general managers of a convenience sample of 475 SMMEs in the region. Time and financial constraints made it impossible to select a bigger sample.

Of the 475 questionnaires distributed, only 250 were suitable for statistical analysis. Given the nature of the data source, descriptive and inferential statistics were calculated using Microsoft Excel 2003 and Statistica (Version 8). 


\section{Results}

\section{Sample description}

As is evident in Table 1, more than two-thirds of the respondents in this sample (69.2\%) were males, which is slightly higher than the overall gender distribution of entrepreneurs in South Africa. Most respondents in this sample (32\%) held a National Certificate or Diploma and had more than 15 years' experience in business (39.2\%). The majority of SMMEs in this sample operated in the personal and business services sectors (42.8\%) or the retailing/wholesaling sector (30.4\%). Grove et al. (1996:56) and Junnila (2004:190) point out that businesses in the service sector contribute significantly to environmental ills, as they have the same energy use and global warming potential as those operating in the manufacturing sector. Based on the classification of SMMEs according to the National Small Business Act (No 102 of 1996), 81.6 percent of businesses in this sample were small (i.e. employing between five and fifty employees).

Table 1: Sample description

\begin{tabular}{|c|c|c|}
\hline Gender & $\mathbf{N}$ & $\%$ \\
\hline Male & 173 & 69.20 \\
\hline Female & 77 & 30.80 \\
\hline Total & 250 & 100.00 \\
\hline Highest level of education & $\mathbf{N}$ & $\%$ \\
\hline Grade 11 or lower & 22 & 8.80 \\
\hline Grade 12 or equivalent qualification & 75 & 30.00 \\
\hline National Certificate or Diploma & 80 & 32.00 \\
\hline Bachelors degree & 43 & 17.20 \\
\hline Honours degree & 15 & 6.00 \\
\hline Master's degree / MBA / Doctorate & 15 & 6.00 \\
\hline Total & 250 & 100.00 \\
\hline Total number of years experience & $\mathbf{N}$ & $\%$ \\
\hline Less than or equal to 1 year & 8 & 3.20 \\
\hline $1>$ years 5 & 60 & 24.00 \\
\hline $5>$ years 10 & 44 & 17.60 \\
\hline $10>$ years 15 & 40 & 16.00 \\
\hline More than 15 years & 98 & 39.20 \\
\hline Total & 250 & 100.00 \\
\hline Branch of industry & $\mathbf{N}$ & $\%$ \\
\hline Manufacturing & 25 & 10.00 \\
\hline Retailing / Wholesaling & 76 & 30.40 \\
\hline Business or personal services & 107 & 42.80 \\
\hline Building and construction & 21 & 8.40 \\
\hline Agriculture / Forestry / Fisheries & 12 & 4.80 \\
\hline Combination of retailing/wholesaling and service provision & 4 & 1.60 \\
\hline Combination of manufacturing and retailing/wholesaling & 5 & 2.00 \\
\hline Total & 250 & 100.00 \\
\hline Classification (based on number of full time employees) & $\mathbf{N}$ & $\%$ \\
\hline Micro (1 - 4 full time employees) & 21 & 8.40 \\
\hline Small (5 - 50 full time employees) & 204 & 81.60 \\
\hline Medium (51 - 199 employees) & 25 & 10.00 \\
\hline Total & 250 & 100.00 \\
\hline
\end{tabular}




\section{Respondents' views on “going green”}

Table 2 indicates the frequency distributions and summary statistics of the statements contained in Section A of the questionnaire.

Table 2: Perceptions on "going green"

\begin{tabular}{|c|c|c|c|c|c|c|c|c|c|}
\hline & & \multirow[t]{2}{*}{ Statement } & \multicolumn{5}{|c|}{ Frequency distribution (\%) } & \multicolumn{2}{|c|}{$\begin{array}{l}\text { Summary } \\
\text { statistics }\end{array}$} \\
\hline & & & 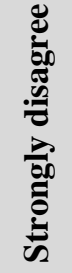 & 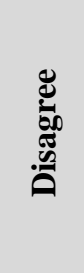 & 를 & 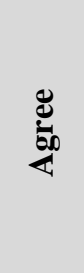 & 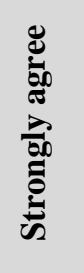 & 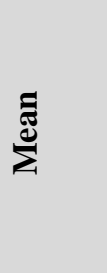 & 常 \\
\hline \multirow{4}{*}{$\begin{array}{l}\text { The level of } \\
\text { environmental } \\
\text { awareness among } \\
\text { SMME } \\
\text { owners/managers }\end{array}$} & S1.1 & $\begin{array}{l}\text { SMME owners in South Africa are } \\
\text { concerned about the impact of } \\
\text { their operations on the } \\
\text { environment. }\end{array}$ & 5.2 & 24.4 & 30.8 & 28.0 & 11.6 & $3.16^{(\mathrm{c})}$ & 1.08 \\
\hline & S1.2 & $\begin{array}{l}\text { SMME owners in South Africa } \\
\text { should become more concerned } \\
\text { about the greening of their } \\
\text { business operations. }\end{array}$ & 0.8 & 0.8 & 5.2 & 50.0 & 43.2 & $4.34^{(\mathrm{a})}$ & 0.69 \\
\hline & S1.3 & $\begin{array}{l}\text { I have become more aware of the } \\
\text { impact that my business operations } \\
\text { have on the environment within } \\
\text { the past } 12 \text { months. }\end{array}$ & 2.4 & 10.4 & 24.4 & 47.6 & 15.2 & $3.63^{(b)}$ & 0.95 \\
\hline & S1.4 & $\begin{array}{l}\text { I prefer to do business with other } \\
\text { "green" businesses. }\end{array}$ & 4.8 & 9.6 & 42.4 & 28.4 & 14.8 & $3.39^{\text {(c) }}$ & 1.01 \\
\hline \multirow{2}{*}{$\begin{array}{l}\text { The level of } \\
\text { engagement among } \\
\text { SMME } \\
\text { owners/managers }\end{array}$} & S1.5 & $\begin{array}{l}\text { I promote environmentally } \\
\text { friendly business practices during } \\
\text { meetings. }\end{array}$ & 1.6 & 10.0 & 41.6 & 32.8 & 14.0 & $3.48^{(b)}$ & 0.91 \\
\hline & S1.6 & $\begin{array}{l}\text { I promote green business practices } \\
\text { among my employees by } \\
\text { providing them with practical } \\
\text { advice via notice boards, } \\
\text { newsletters, the intranet etc. }\end{array}$ & 4.4 & 16.0 & 40.4 & 30.4 & 8.8 & $3.23^{(\mathrm{c})}$ & 0.97 \\
\hline \multirow{2}{*}{$\begin{array}{l}\text { The financial } \\
\text { implications of } \\
\text { "going green" }\end{array}$} & S1.7 & $\begin{array}{l}\text { It is not expensive to adopt greener } \\
\text { business practices. }\end{array}$ & 3.6 & 18.0 & 38.4 & 32.8 & 7.2 & $3.22^{(\mathrm{c})}$ & 0.95 \\
\hline & S1.8 & $\begin{array}{l}\text { I can improve my firm’s } \\
\text { profitability by implementing } \\
\text { greener business practices. }\end{array}$ & 5.6 & 17.2 & 35.2 & 33.6 & 8.4 & $3.22^{(\mathrm{c})}$ & 1.01 \\
\hline \multirow[t]{3}{*}{$\begin{array}{l}\text { Measures to } \\
\text { promote "greener" } \\
\text { business practices }\end{array}$} & S1.9 & $\begin{array}{l}\text { The government should encourage } \\
\text { environmentally friendly business } \\
\text { practices by means of tax } \\
\text { incentives. }\end{array}$ & 1.6 & 3.6 & 8.8 & 44.0 & 42.0 & $4.21^{(\mathrm{a})}$ & 0.87 \\
\hline & S1.10 & $\begin{array}{l}\text { Stricter government legislation on } \\
\text { environmental issues is required in } \\
\text { South Africa. }\end{array}$ & 0.8 & 4.8 & 10.8 & 45.2 & 38.4 & $4.16^{(\mathrm{b})}$ & 0.86 \\
\hline & S1.11 & $\begin{array}{l}\text { Stricter enforcement of } \\
\text { environmental legislation is } \\
\text { required in South Africa. }\end{array}$ & 0.4 & 2.8 & 14.0 & 42.0 & 40.8 & $4.20^{(\mathrm{a})}$ & 0.81 \\
\hline \multicolumn{10}{|c|}{$\begin{array}{l}\text { (a) Very high level of agreement (mean scores } 4.2-5 \text { ) } \\
\text { (b) High level of agreement (mean scores } 3.4-4.2 \text { ) } \\
\text { (c) Average level of agreement (mean scores } 2.6-4.3 \text { ) }\end{array}$} \\
\hline
\end{tabular}




\section{The level of environmental awareness and engagement among SMME owners/managers}

Based on the statistics in Table 2, 62.8 percent of SMME owners/managers in the sample had a heightened awareness of the effect of their operations on the natural environment and the importance of reducing their ecological footprint. Due to their own heightened sensitivity, 93.2 percent of respondents stated that more SMME owners/managers in the country ought to become concerned about the environment. Despite respondents becoming seemingly more environmentally conscious, only 46.8 percent promoted environmentally friendly business practices during meetings. Fewer yet (only 39.2\% of respondents) promoted "green” business practices among their employees by providing them with practical advice via notice boards, newsletters, the intranet, and so on. These finding are similar to those of Horobin and Long (1996:17) and Yu and Bell (2007:40), who found that a high level of concern for the environment does not necessarily translate into a high level of engagement by SMME owners/managers.

\section{The financial implications of "going green"}

More than half of the respondents (56.4\%) were of the opinion that it is expensive to adopt "green" business practices and only 42 percent agreed that enhanced environmental management could improve profitability. This finding supports Revell's (2002:291) argument that low levels of engagement often result from the perception that environmental and economic interests are at odds. Only 21 respondents (or 8.4\%) indicated that they had a budget for the implementation of "greener" business practices. Of these 21 respondents, 38.1 percent had budgets of between one and five percent of annual turnover. The rest had smaller budgets.

\section{Measures to promote “greener” business practices}

Eighty six percent of respondents indicated that the South African government should encourage "greener" business practices by means of tax incentives or through stricter legislation (83.6\%) and improved law enforcement (82.8\%). As indicated in the literature review, both the scope and enforcement of environmental laws in South Africa have improved in recent years. Respondents' calls for increased green legislation might therefore arise from a lack of knowledge about the range and nature of existing environmental laws. Hillary (2000:60) found that small business managers were often unaware of the relevant laws, regulations and ordinances in their sectors.

As indicated in Table 3, three statements correlated significantly with statement S1.6 ("I promote 'green' business practices among my employees by providing them with practical advice via notice boards, newsletters, the intranet etc.”). These three statements are:

S1.2 - SMME owners in South Africa should become more concerned about the "greening" of their business operations;

S1.4 - I prefer to do business with other "green” businesses; and

S1.8 - I can improve my firm's profitability by implementing greener business practices. 
Table 3: Pearson correlations matrix

\begin{tabular}{|c|c|c|c|c|c|c|c|c|c|c|c|}
\hline & S1.1 & $\begin{array}{l}\text { S1.2 } \\
\end{array}$ & $\begin{array}{l}\text { S1.3 } \\
\end{array}$ & S1.4 & S1.5 & S1.6 & S1.7 & $\begin{array}{l}\text { S1.8 } \\
\end{array}$ & S1.9 & S1.10 & S1.11 \\
\hline S1.1 & 1.00 & 0.11 & -0.03 & 0.39 & -0.16 & 0.32 & 0.32 & 0.40 & -0.16 & 0.24 & -0.34 \\
\hline S1.2 & & 1.00 & 0.18 & -0.12 & -0.16 & 0.44* & 0.35 & 0.15 & 0.01 & 0.01 & 0.25 \\
\hline $\begin{array}{l}\text { S1.3 } \\
\end{array}$ & & & 1.00 & -0.12 & -0.07 & 0.15 & 0.08 & 0.29 & -0.15 & 0.48* & 0.44* \\
\hline S1.4 & & & & 1.00 & 0.18 & $0.62 *$ & 0.14 & 0.41 & -0.28 & 0.08 & -0.39 \\
\hline S1.5 & & & & & 1.00 & -0.03 & 0.13 & 0.32 & $0.46^{*}$ & 0.00 & 0.13 \\
\hline S1.6 & & & & & & 1.00 & 0.30 & 0.54* & -0.18 & 0.17 & 0.02 \\
\hline S1.7 & & & & & & & 1.00 & 0.33 & 0.27 & 0.15 & 0.17 \\
\hline S1.8 & & & & & & & & 1.00 & 0.05 & 0.22 & 0.09 \\
\hline S1.9 & & & & & & & & & 1.00 & 0.10 & 0.42 \\
\hline S1.10 & & & & & & & & & & 1.00 & 0.26 \\
\hline S1.11 & & & & & & & & & & & 1.00 \\
\hline
\end{tabular}

* Significant at the 95\% level

S1.1: Stricter enforcement of environmental legislation is required in South Africa.

S1.2: SMME owners in South Africa should become more concerned about the greening of their business operations.

S1.3: I have become more aware of the impact that my business operations have on the environment within the past 12 months.

S1.4: I prefer to do business with other "green" businesses.

S1.5: I promote environmentally friendly business practices during meetings.

S1.6: I promote green business practices among my employees by providing them with practical advice via notice boards, newsletters, the intranet etc.

S1.7: It is not expensive to adopt greener business practices.

S1.8: I can improve my firm's profitability by implementing greener business practices.

S1.9: The government should encourage environmentally friendly business practices by means of tax incentives.

S1.10: Stricter government legislation on environmental issues is required in South Africa.

S1.11: Stricter enforcement of environmental legislation is required in South Africa.

The correlation of S1.6 with the first two statements seems to refer to calls by "green" SMMEs for a level playing field in the country. Respondents appear to think that uniform environmental standards and costs can only be achieved through regulation. Other studies support this argument (SMEs 'not convinced of need to go green', 2004:6). The same interpretation applies to the next set of correlations, where statement S1.3 ("I have become more aware of the impact that my business operations have on the environment within the past 12 months.”) significantly correlates with:

S1.10 - Stricter government legislation on environmental issues is required in South

Africa; and

S1.11 - Stricter enforcement of environmental legislation is required in South Africa.

Although research by Dahlmann et al. (2008:264) and Yu and Bell (2007:19) suggests that legislative compliance is a major motivator for SMMEs to engage in "greening' actions, Clemens (2006:493) warns that the burden of regulation is often greater on SMMEs than on larger businesses. This is because larger companies are better at challenging burdensome regulations, more insulated from bans or reductions on inputs due to green concerns, better at predicting regulatory changes (which allows them to respond more effectively to them) and more likely to adopt corporate-wide "green" improvements. 
The desirability of more and stricter environmental laws applicable to local SMMEs is questionable, as the regulatory burden on SMMEs has already been identified as one of the main inhibitors of entrepreneurial activity in South Africa (Mahadea \& Pillay, 2008:431; Maas \& Herrington, 2006; Clover \& Darroch, 2005:238). This is due to the fact that increased legislation calls for more record keeping, which in turn results in higher administrative and labour costs. Statement S1.9 ("The government should encourage environmentally friendly business practices by means of tax incentives.") also significantly correlates with statement S1.5 ("I promote environmentally friendly business practices during meetings.”). This finding suggests that respondents who engage in "green" actions (which could be costly to implement in some instances) want the government to recognise and reward their efforts.

No significant correlations were found between the statements in this section and the biographical details of the respondents and their businesses.

\section{“Green” business practices}

As the data sourced in Section B of the questionnaire were nominal in nature, the interpretation thereof is limited to frequency distributions. The following discussion will centre on four categories of "green" actions, namely pollution prevention, solid waste reduction, energy conservation and water conservation.

\section{Pollution prevention}

Almost half of the respondents in the sample (47.6\%) identified ways in which to reduce the use of hazardous materials. A large percentage of SMME owners/managers (65.5\%) purchased hazardous products in small quantities and limited access thereof to trained and authorised employees only (56.8\%). More than half the SMME owners/managers (54\%) in this sample have already reduced the use of chemical pesticides by correcting the situations that attract and harbour pests (e.g. through the proper storage and disposal of food and garbage).

Although less than a third of the respondents (31\%) had replaced hazardous products with safer alternatives in the past year, several (19.5\%) intended doing so in the next 12 months. Examples of hazardous products that have been replaced with "greener" alternatives include ammonia-based cleaners and acrylic enamels. A few respondents (15\%) indicated that they had changed suppliers due to the chemical contents in their suppliers' products being “too high". Several (19\%) began to purchase more biodegradable and eco-friendly products, and one respondent, the owner of a nursery, remarked that they were planting insect-repellent plants to reduce their reliance on insecticides.

Large numbers of respondents (46\%) replaced standard fluorescent lights with nonmercury fluorescent lights, used rechargeable batteries rather than single-use batteries (48.8\%) and bought paper products such as towels, napkins and unbleached copy paper (44.8\%). Several respondents intended doing so in the next 12 months (18.4\%, 15.6\% and $25.2 \%$ respectively). These statistics support the finding that more SMME owners/managers are becoming aware of the effects that hazardous materials have on the natural environment. 
An important element in pollution prevention is recycling. In businesses where grease, oil and paint were used, an almost equal split was observed between respondents who recycled these liquids and those who did not. Very few respondents (7.2\%) recycled spent fluorescent tubes, which is regrettable, given that these products contain small quantities of mercury, cadmium and antimony. Research shows that once these toxins are released at landfills they contaminate soil and water sources for years to come (Recycling fluorescent lamps, 2006).

Only 36.4 percent of respondents regularly informed their employees on the need to dispose of/recycle hazardous liquids and of ways of doing this. This finding corresponds with the disappointing statistics in Table 2, which shows that few respondents (46.8\%) promoted environmentally friendly business practices during meetings or via other communication channels (39.2\%). Close to a quarter of respondents (22.4\%) were contemplating the use of recycling companies in the near future, and 27.6 percent were planning to step up their communication efforts in this regard in the foreseeable future.

With regard to the reduction of air pollution, 51.2 percent of respondents planned business trips to accomplish all their errands in one outing and 34 percent encouraged lift clubs among employees. These findings should, however, be interpreted with caution, as SMME owners/managers could have encouraged these types of activities due to high fuel prices at the time of the survey and not necessarily because they wanted to reduce their carbon emissions.

\section{Solid waste reduction}

Thirty-one percent of respondents said that solid waste assessments were not applicable to their businesses. This statistic might be indicative of the fact that SMME owners/managers did not have a clear understanding of what solid waste entails. The same argument applies to the 18 percent of respondents who stated that the implementation of a solid waste recycling programme did not apply to their businesses. SMME owners/managers need to realise that all businesses, irrespective of their size and operations, generate solid waste and that they have to dispose of it in a proper manner.

Although some SMME owners/managers might not have had a clear picture of what solid waste entails, others endeavoured to reduce solid waste by buying products in returnable, re-useable or recyclable containers (52\%), storing and rotating supplies to minimise losses through spoilage and damage (51.6\%) and buying products that use less packaging material (37.2\%). These findings confirm the growing level of environmental awareness among respondents and their desire to do business with other "green" enterprises.

With regard to office paper reduction, SMME owners/managers encouraged employees to keep a stack of previously used paper near printers (78\%), re-use the reverse side of scrap paper and drafts of internal memos (68.4\%) and use computer software programs that allow faxing directly from computers without printing (54.8\%). A further 40 percent of SMME owners/managers recycled toner cartridges, with a further 12.8 percent planning to do so in the next 12 months.

Despite the above mentioned efforts to reduce solid waste, 37.2 percent of respondents still do not set their printer and copier defaults to double sided, or use marketing 
materials that require no envelope, such as fold-and-mail envelopes (34\%). It should be noted that these seemingly small "greening" actions could lead to substantial benefits for SMMEs (in terms of cost savings) and the environment (in terms of preserving forests and reducing waste dumps).

An unsettling finding is that a large number of respondents fail to recycle newspapers (42\%) and wood/paper-based products (33.2\%). Few SMME owners/managers (18\%) buy re-used or recycled paper products such as table covers, napkins, placemats, toilet seat covers and toilet paper. This is unfortunate, as the depletion of forests is the secondlargest contributor to greenhouse gas emissions in the world (Lovejoy, 2008:77). Clearly, SMME owners/managers need to be educated on the importance of recycling woodbased products and supporting sustainable forestry practices.

Thirty percent of respondents also felt that the recycling of glass, plastic or aluminium containers with a deposit value did not apply to their businesses. As stated previously, this might be due to the fact that they do not know where and how to recycle these products in their region.

\section{Energy conservation}

Due to the timing of this study (the period when Eskom's load-shedding was at its worst - April and May 2008), it comes as no surprise that most respondents were acutely aware of saving electricity. The percentages of respondents who already engaged in energy conservation measures at the time of the survey are indicated in Table 4.

Table 4: Energy conservation measures

\begin{tabular}{|l|c|}
\hline & $\begin{array}{c}\text { “Yes, I } \\
\text { currently do } \\
\text { it” }\end{array}$ \\
\hline $\begin{array}{l}\text { I know which factors have a direct impact on the electricity / energy consumption of my } \\
\text { business. }\end{array}$ & $82.0 \%$ \\
\hline I know how much electricity / energy is consumed in my business on a monthly basis. & $80.8 \%$ \\
\hline I ensure that my employees are energy conscious. & $70.0 \%$ \\
\hline $\begin{array}{l}\text { I have a policy that all electronic devices and lights are switched off in non-occupied } \\
\text { rooms. }\end{array}$ & $68.8 \%$ \\
\hline I see energy management as an integral part of the way I do business. & $65.6 \%$ \\
\hline I have guidelines to quantify my energy costs against my production quality. & $39.2 \%$ \\
\hline $\begin{array}{l}\text { I measure the energy usage of major equipment (e.g. motors, fan, compressors, pumps } \\
\text { etc.) in my business. }\end{array}$ & $39.2 \%$ \\
\hline I ensure that my employees are skilled in energy management practices. & $37.2 \%$ \\
\hline I encourage employees to turn off lights where possible. & $92.0 \%$ \\
\hline
\end{tabular}

Due to the rising costs of electricity and a looming power crisis in the country, many respondents indicated that they would consider the implementation of an energy management system and the use of ballasts in the near future $(18.8 \%$ and $24.8 \%$ respectively). A ballast is an electrical component used to conduct electricity at each end of the tube. It supplies the initial electricity to the bulb that creates light and then regulates the amount of electricity flowing through the bulb so that it emits the right amount of light. According to Eskom (2008), the use of ballasts can considerably reduce a firm's electricity bill. 
More than two-thirds of the respondents (67.2\%) replaced standard light bulbs with compact fluorescent bulbs. According to Eskom (2008), compact fluorescent bulbs last over ten times longer and use up to four times less energy than standard bulbs. Other energy-saving measures undertaken by respondents included:

regularly repairing cracks, broken windows, and other places where infiltration of unconditioned air can take place (62.8\%);

ensuring that the layout of their building(s) enabled adequate airflow (which reduces the energy consumption of their heating, ventilation and air conditioning system) (44.4\%); and

keeping doors closed between airconditioned and non-airconditioned spaces (e.g. through the use of automatic or self-closing doors) (42.4\%).

\section{Water conservation}

With regard to water conservation measures, 78.8 percent of SMME owners/managers know how to read their water meter and water bill as a means of detecting leaks. A further 84.4 percent of respondents regularly checked and repaired leaks. As indicated in Table 5, the majority of respondents have no measures in place to reduce their water consumption (although many of the measures are easy to install and cost effective). Not many indicated that they were considering doing so in the next 12 months. This is very unfortunate as South Africa is a water-scarce country.

Table 5: Water conservation measures

\begin{tabular}{|l|c|c|}
\hline & $\begin{array}{c}\text { “Not doing it } \\
\text { currently" }\end{array}$ & $\begin{array}{c}\text { "Not doing it } \\
\text { currently, but } \\
\text { considering it in the } \\
\text { next 12 months" }\end{array}$ \\
\hline I have ultra low-flow toilets installed in my business. & $52.8 \%$ & $13.6 \%$ \\
\hline I have quick-closing toilet flappers in place. & $42.8 \%$ & $11.6 \%$ \\
\hline $\begin{array}{l}\text { I have signs in our restrooms encouraging water } \\
\text { conservation. }\end{array}$ & $41.6 \%$ & $18.8 \%$ \\
\hline $\begin{array}{l}\text { I have low-flow aerators for sinks, faucets, lavatory sinks } \\
\text { and kitchen sinks. }\end{array}$ & $39.6 \%$ & $14.8 \%$ \\
\hline
\end{tabular}

As indicated in Table 6, only some of the above-mentioned few "green" actions correlated with the biographical data of the respondents (all of them negatively). 
Table 6: Correlations between "green” actions and respondents' biographical data

\begin{tabular}{|l|c|c|c|c|}
\hline \multicolumn{1}{|c|}{ Statements } & Mean & $\begin{array}{c}\text { Total } \\
\text { Standard } \\
\text { deviation }\end{array}$ & $\begin{array}{c}\text { number of } \\
\text { years } \\
\text { business } \\
\text { experience }\end{array}$ & Gender \\
\hline $\begin{array}{l}\text { S2.20: I link business trips to accomplish all } \\
\text { errands for my facility in one outing. }\end{array}$ & 1.97 & 1.17 & -0.194 & -0.200 \\
\hline $\begin{array}{l}\text { S3.13: I keep a stack of previously used } \\
\text { paper near printers; re-use the reverse side for } \\
\text { scratch paper and drafts of internal memos. }\end{array}$ & 1.49 & 0.85 & -0.177 & \\
\hline $\begin{array}{l}\text { S3.22: For the shipping of non-food items I } \\
\text { use shredded paper for my packing needs } \\
\text { instead of purchasing Styrofoam pellets, } \\
\text { bubble wrap and other types of packaging } \\
\text { material. }\end{array}$ & 2.98 & 1.17 & & -0.163 \\
\hline $\begin{array}{l}\text { S4.21: I regularly clean lighting fixtures and } \\
\text { lamps so that they are lighting as effectively } \\
\text { as possible. }\end{array}$ & 1.57 & 0.88 & & -0.172 \\
\hline $\begin{array}{l}\text { S5.3: I have low-flow aerators for sinks, } \\
\text { faucets, lavatory sinks and kitchen sinks. }\end{array}$ & 2.14 & 1.01 & & -0.184 \\
\hline $\begin{array}{l}\text { S5.13: I wash exterior windows with a bucket } \\
\text { and squeegee rather than with a power hose. }\end{array}$ & 1.437247 & 0.960135 & -0.195 & \\
\hline
\end{tabular}

All correlations were statistically significant at the 95\% confidence level

Closer investigation revealed that older respondents (those with more than 10 years' experience) and men were less likely to engage in these "green" actions. This could be attributed to younger respondents being more conscious of environmental matters and women being more value-based in their approach to management. Research in the field of responsible investing also reveals that more women and younger investors are investing in funds which explicitly consider ethical, environmental, social and corporate governance issues (McLachlan \& Gardner, 2004:13; Schueth, 2003:195; Rosen \& Sandler, 1999:221; Hutton, D’Antonio \& Johnsen, 1998:281).

\section{DISCUSSION}

The empirical findings indicate that the majority of SMME owners/managers in this sample had a heightened awareness of the effect their operations are having on the natural environment. Due to their own heightened sensitivity, respondents also suggested that more SMME owners/managers in South Africa are becoming concerned with the "greening" of their business practices. Their high level of concern for the environment, however, does not translate into a high level of engagement, a finding which corresponds to research conducted by Horobin and Long (1996:17), as well as that of Yu and Bell (2007:19). SMME owners/managers in this sample also view the adoption of "green" business practices as expensive and fail to recognise that environmental management could lead to improved profitability.

Respondents view the role of government as very important in promoting improved environmental management in the local SMME sector. The respondents expressed very strong views in favour of increased environmental legislation, stricter enforcement of these laws and tax incentives. These findings correspond with those of Shange (2008:99) 
and Clemens (2006:492). Questions could, however, be raised about the desirability of increasing the regulatory burden on local SMMEs.

The empirical evidence further reveals that the "green" actions of SMMEs in this sample mainly dealt with conserving electricity, recycling paper and replacing hazardous materials with more eco-friendly alternatives.

\section{Implications and recommendations}

When considering the significant environmental footprint of the SMME sector as a whole and the dire consequences of climate change, it is clear that SMME owners/managers have an important role to play as change agents. It is thus suggested that more research be conducted on environmental management in the local SMME sector and that the findings be communicated to SMME owners/managers via appropriate channels (such as the general media and dedicated SMME websites, newspapers and publications). It is of particular importance that SMME owners/managers become better informed about existing environmental legislation and incentives, the financial benefits of "going green" and their role in terms of environmental conservation.

SMME owners/managers should note that small, seemingly insignificant "green" actions could have large payoffs and that the benefits of implementing an environmental management system generally outweigh the costs thereof. It is suggested that SMME owners/managers build on the "green" efforts currently undertaken and that more attention be given to water conservation and recycling initiatives. Finally, it is suggested that environmental education should be more strongly integrated into business and ethics curricula at tertiary education institutions.

\section{Limitations of the study}

As this research only evaluated the "green" perceptions and actions of 250 SMME owners/managers in the Eastern Cape, it is suggested that the study be extended to include SMMEs in other provinces too (especially the more affluent provinces of Gauteng and the Western Cape). The questionnaire could also be refined to allow for a more sophisticated statistical analysis.

\section{Conclusion}

South African SMME owners/managers have an important role to play in conserving our natural environment and limiting the factors causing climate change. The growing environmental concern among SMME owners/managers needs, however, to be translated into concrete "green" business practices. Such actions will not only lead to improved profitability for the SMMEs involved, but also a sustainable future for all South Africans. 


\section{References}

Benjamin, C. 2007. Green Scorpions target Gauteng polluters. Business Day, 10 July. (1p). [Online] Available from: http://www.businessday.co.za/articles/topstories.aspx?ID=BD4A512546 [Accessed: 200711-05].

Burger, A. 2007. Climate change and business: the carbon disclosure project, 27 November. (1p). [Online] Available from: http://www.triplepundit.com/pages/climate-change-business-the-ca-002737.php [Accessed: 2008-02-14].

Cairncross, F. 1995. Green Inc: a guide to business and the environment. London: Earthscan.

Cameron, B. 2006. State pension fund to turn up heat on corporate SA. Personal Finance, 26 May. (2p). [Online] Available from: http://www.persfin.co.za/index.php?fSectionId=595\&fArticleId=3264739 [Accessed: 2007-11-04].

Church, J. 2006. Sustainable development revisited: the protection of small business enterprises and the environment as national assets with reference to global trends and recent government policy. Orbiter, 27(3):628-635.

Clark, A. 2007. Practical advice for greening the SME: Views from the States: practical advice for greening the SME. (6p). [Online] Available from: http://wwwblog.businessgreen.com/2007/05/ view_from_the_s.html [Accessed: 2007-11-05].

Clemens, B. 2006. Economic incentives and small firms: Does it pay to go green? Journal of Business Research, 59:492-500.

Clover, T.A. \& Darroch, M.A.G. 2005. Owners' perceptions of factors that constrain the survival and growth of small, medium and micro agribusineses in KwaZulu-Natal, South Africa. Agrekon, 44(2):238263.

Dahlmann, F., Brammer, S. \& Millington, A. 2008. Environmental management in the United Kingdom: new survey evidence. Management Decision, 46(2):264-283.

De Villiers, C.J. 2004. Ethical arguments regarding corporate environmental reporting. Meditary Accountancy Research, 12(1):21-38.

Do you need to be green? 2006. Business Week, Summer. (3p). [Online] Available from: http://www.businessweek.com/magazine/content/06_25/b3989601.htm [Accessed: 2007-11-06].

Ensor, L. 2008. Heavier pollution penalties on cards. Business Day, 29 February. (1p). [Online] Available from: http://www.businessday.co.za/articles/article.aspx?ID=BD4A717038 [Accessed: 2008-03-05].

Eskom. 2008. Demand size management. (3p). [Online] Available from: http://www.eskomdsm.co.za/ [Accessed: 2008-05-17].

Go green: start recycling in your small business. 2006. NFIB - the voice of small business, 14 June. (5p). [Online] Available from: http://www.nfib.com/object/IO_28768.html [Accessed: 2008-02-15].

Grove, S.J., Fisk, R.P., Pickett, G.M. \& Kangun, N. 1996. Going green in the service sector. European Journal of Marketing, 30(5):56-66.

Hillary, R. 2000. Small and medium-sized enterprises and the environment. Sheffield: Greenleaf.

Hills, P., Lam, J. \& Welford, R. 2004. Business environmental reform and technological innovation in Hong Kong. Business Strategy Environment, 13:223-234.

Hopfenbeck, W. 1992. The management revolution: lessons in environmental excellence. London: Prentice Hall. 
Horobin, H. \& Long, J. 1996. Sustainable tourism: the role of the small firm. International Journal of Contemporary Hospitality Management, 8(5):15-19.

Hutton, R.B., D’Antonio, L. \& Johnsen, T. 1998. Socially responsible investing. Business and Society Magazine, 37(3):281-306.

Junnila, S. 2004. The environmental significance of facilities in service sector companies. Facilities, 22(7/8):190-198.

Kapelus, P., Hamman, R., Agbazue, T. \& Hein, A. 2004. Corporate social responsibility: implications for an ISO standard. Johannesburg: African Institute of Corporate Citizenship.

Le Riche, L. 2008. Bring on the green. Your Business, 13(2):26-29.

Lesourd, J.B. \& Schilizzi, G.M. 2001. The environment in corporate management: new direction and economic insights. Cheltenham: Edward Elgar.

Lovejoy, T. 2008. The threat from trees. Newsweek Special Report: Environment, CLII(01/01):77.

Maas, G. \& Herrington, M. 2006. Global Entrepreneurship Monitor: South African Executive Report. Cape Town: UCT Graduate School of Business, University of Cape Town.

Mahadea, D. \& Pillay. M.K. 2008. Environmental conditions for SMME development in a South African province. South African Journal of Economics and Management Sciences, 11(4):431-448.

Mattheus, B. 2007. Verbal communication (telephonic discussion) with the Editor of the Nelson Mandela Bay 2007 Business Guide on 1 April. Port Elizabeth.

McLachlan, J. \& Gardner, J. 2004. A comparison of socially responsible and conventional investors. Journal of Business Ethics, 52(1):11-25.

McDonagh, P. \& Prothero, A. (Eds). 1997. Green management: a reader. London: Dryden.

Millet, L. 2000. The green office manual: a guide to responsible practice. $2^{\text {nd }}$ ed. London: Earthscan.

Mitchell, C.G. \& Quinn, N.W. 2005. Environmental reporting disclosure in South Africa: a comparative study of the expectations of selected groups of preparers and users. Meditary Accountancy Research, 13(2):17-33.

Mokgata, L. 2008. Going green takes on new meaning for retailers. (4p). [Online] Available from: http://www.bizcommunity.com/rss/196/306.html [Accessed 2008-04-06].

Newton, L.H. 2005. Business ethics and the natural environment. Cornwell: Blackwell.

Peattie, K. 1995. Environmental marketing management: meeting the green challenges. London: Pitman.

Recycling fluorescent lamps. 2006. (2p). [Online] Available from: http://www.govlink.org/hazwaste/ publications/FluorescentRecycling_2006.pdf [Downloaded: 2008-02-04].

Revell, A. 2002. Ecological modernisation of small firms in Japan. Environmental Economics and Policy Studies, 5:291-317.

Robertson, D. 2008. Green buildings are all the rage. Sunday Times, 2 March:6.

Rosen, B.N. \& Sandler, D.M. 1991. Social issues and socially responsible investment behaviour: a preliminary investigation. Journal of Consumer Affairs, 25(2):221-235.

SA considering carbon taxes. 2008. ESI-Africa.com. 29 July. (3p). [Online] Available from: http://www.esi-africa.com/node/9505 [Accessed: 2008-07-29]. 
Salgado, I. 2008. Green moves by money. Personal Finance, 15(1 $1^{\text {st }}$ quarter $): 25$.

Schaltegger, S. \& Figge, F. 1998. Environmental shareholder value. WWZ/Sarasin basic report. Study no 54:1-42.

Schubert, M. \& Nel, G. 2008. Going green may save cash. Business Day, 10 March. (2p). [Online] Available from: http://www.businessday.co.za/articles/article.aspx?ID=BD4A723103 [Accessed: 2008-0311].

Schueth, S. 2003. Socially responsible investing in the United States. Journal of Business Ethics, 43(3):189-194.

Shange, M.N. 2008. An investigation of the mechanisms which promote "greener" business practices in South Africa. Unpublished BCom Honours thesis, Nelson Mandela Metropolitan University: Port Elizabeth.

Sharma, S. \& Vrendenburg, H. 1998. Proactive corporate environmental strategy and the development of competitively valuable organizational capabilities. Strategic Management Journal, 19:729-753.

SMEs 'not convinced of need to go green'. 2004. IEE Review, Mid-July:6. (2p). [Online] Available from: http://www.ieereview.org [Accessed: 2008-02-08].

South African Business Guidebook 2005/2006. 2006. $11^{\text {th }}$ ed: Johannesburg: WriteStuff Publishing.

South Africa. 1996. National Small Business Act, No. 102 of 1996. Government Gazette, 17612(1901). (14p), (27p). [Online] Available from: http://www.info. gov.za/ gazette/acts/1996/a102-96.pdf. [Downloaded: 2006-01-07].

South Africa. DEAT (Department of Environmental Affairs and Tourism). 2006. Environment Outlook 2006. (45p). [Online] Available from: http://www.environment.gov.za [Accessed: 2007-03-11].

Stern, N. 2007. The economics of climate change - the Stern review. Cambridge: Cambridge University Press.

Viviers, S., Bosch, J.K., Smit, E.vdM. \& Buijs, A. 2008. Is responsible investing ethical? South African Journal of Business Management, 39(1):15-25.

World Commission on Environment and Development. 1987. Our common future. Oxford: Oxford University Press.

Yu, J. \& Bell, J.N.B. 2007. Building a sustainable business in China's Small and Medium-sized Enterprises (SMEs). Journal of Environmental Assessment Policy and Management, 9(1):19-43. 